\title{
Clint Jewson
}

\section{I don't understand}

I've been squirming in my seat for over an hour, my new suit pants itching my arse.

I was nervous, now I'm just bored.

The office is small, square and plain; blue carpet, white walls, a fluorescent light buzzing down over a metal desk and two plastic chairs. No windows, no pictures, not even a plant. A stream of cold air rattles out of a duct above me. This room is not what I'd expected at all. I'd pictured glass windows looking over the river, plush chairs, roving dignitaries; something more, I don't know, United Nations.

The office is adjoined by a dimly lit storeroom: concrete floor, bare block walls, rows of metal shelves stacked with boxes. A young guy is shuffling about in there amongst the shelves. I hope that isn't where I'm gonna' be working. I force myself to sit up straight. Eventually the door behind me opens and Peter, the guy who met me in the lobby, walks in.

'Oh, yes, James, wasn't it?'

I sit up straighter, nod politely. He drops heavily into the chair across from me, smiles and takes a single sheet of paper from a manila file. I squirm until he's finished reading. here.'

'Well, there's not a single thing on this piece of paper that tells me why you're

My eyes drop to the desk between us. 'Err, my dad got me this internship sir.'

He leans back looking me over. 'I guessed as much, the Australian Ambassador ...' He trails off and I can tell he's bored. 'Regardless, we're going to treat you the same as any other intern.'

'Yes, sir.'

He stands, pacing in the small space behind the desk. 'So, how much do you know about what the job involves?'

I can't meet his eye. 'To be honest, sir, pretty much nothing.'

'Ha', just doing what you're told, eh. I like that.'

I nod at the desk. 'Yes sir, I guess I'm just kind of along for the ride.'

He throws his head back and laughs, walks over and slaps me on the back. 'Good to hear son, because going on a ride you are.'

Past him, in the storeroom, the young guy moves quietly along the shelves. Peter follows my glance.

'I know it isn't much, but it's an important job you'll be doing. Did your father explain that the training is immersive?'

'No sir.' My shoulder hurts as his grip tightens.

'Best I just show you.' 
His fist connects to my face and the world fades out to darkness.

I come to on my back. My head pounds and I can taste blood in my mouth. I'm too scared to open my eyes. I try and lay very still but when a voice whispers out of the darkness in a language I don't understand I shrink away, kicking blindly across the floor until I'm pressed up hard against a wall. A dream, a nightmare, this isn't real. I close my eyes tight and wait. A flashlight clicks on and my eyelids burn pink but I do not open them. I do not want to see.

'No Arabic? English, yes?'

I push myself deeper into the wall.

'Please be careful, it's very unstable down here, it's not safe to push against the wall like that.'

Dreaming, I'm dreaming.

'Please, please come away from the wall.'

There's real fear in the voice now, so I force open my eyes. The dirt space is tiny, more burrow than cave. In one corner a wooden beam props a piece of ply up against the low dirt ceiling. Two boys are squat in front of me, maybe thirteen or fourteen, looking fragile and confused, a torch pushed into the dirt floor between them.

'What is this?' I beg. 'Where am I?'

Both boys are already crawling away from me towards a tiny tunnel dug through the dirt wall behind them.

'I am Bassam,' says the larger of the two over his shoulder, 'and this is Khaled. Come quickly, we have not finished the ceiling down here, it is not safe.'

The little one slips into the tunnel, Bassam waves the torch for me to follow, then vanishes. The light fades and the darkness pushes me after them. There's only just enough room for me to edge into the entrance on my hands and knees before the ceiling lowers and I'm forced down onto my stomach. I struggle, panting, trying to keep up with the fading light. After a few metres the angle rises sharply and the crawl becomes a climb. Past Khaled I can only catch glimpses, brief flashes of a patchwork ply wood ceiling and faded cardboard walls. I don't know how far we climb, I just kick and pull and scrabble to keep up with the light, the darkness closing in behind, pulling myself forward until the tunnel levels out and opens into a larger, less suffocating space. I roll onto my back, spit out a mouthful of dirt and heave down deep breaths.

We're in a proper tunnel now, at least six feet high maybe two feet wide, dirt floor but concrete walls and arched ceiling. I can't see how deep it goes, the shadows swallow the floor after a metre or two.

'There's no one here. We're safe.' They both watch me with curious, patient expressions. In the dim torchlight I notice I've wet my pants. I don't remember doing it and ... and these are not my pants, I'm wearing faded blue jeans, a dirty white tshirt and an old pair of sneakers, just like the two boys. It's not cold but I start to shake.

'Please, tell me what's going on.' 
Bassam watches me for a moment before he answers. 'We dig that tunnel every night. When we got here tonight you were curled up in a ball. We thought you were dead.'

He tilts his head and watches me, in no hurry, seemingly under no stress.

'Please', I sob, 'I don't understand. Where are we, what is this?' Bassam picks up the torch and stands, Khaled follows. 'Come, we will show you.'

I scramble to my feet and hurry after them. The tunnel continues straight - it looks rough but strong. Cables, wires and a green hose running along the walls, held on every few metres by metal brackets. The dirt floor is littered with broken buckets, torn hessian sacks and squashed cigarette packets. Bassam grabs hold of a metal ladder and starts to climb. stay here.'

'Come,' he calls down quietly, 'Khaled does not like it above ground, he will

The vertical tunnel is round and straight, like a well. I cannot see the top. I keep my eyes on Bassam and the dancing light. We've climbed a long way, maybe twenty or thirty metres, when the wavering light above blinks off and I freeze.

'You're almost there,' Bassam whispers from above, 'come'.

Two more rungs, his small hand grips mine and he pulls me upward into more darkness. A light breeze strokes my sweat-drenched face, calming me, but the sky, the sky is all wrong; pure black, no moon, no stars, like it isn't really there at all, like everything just suddenly stops. A dead scary sky so close it feels like I could almost reach out and touch it.

'Hassan, the sky...'

He sighs. 'The sky is darker than it was, we don't know why. A few months ago it changed. We no longer have sunset or sunrise, no moon, no stars. The light simply turns on in the morning and disappears at night. Even the moon has forgotten us.'

I stumble after him up a small rise, my feet skidding and slipping on the unstable rubble. There's some ambient light and my surroundings slowly take shape. A world in ruins, destroyed, shattered. Undulating piles of broken concrete, twisted metal reaching up like teeth. Faint lights glow from between holes and missing walls of what were once buildings.

'Are there people in there?'

He nods his head beside me.

'Are they homeless?'

'No my friend, these are their homes.'

I can sense salt on the breeze and I wonder if we're near the sea. In the far distance, just over the pile of broken rubble, a tiny string of lights stretches across the horizon. Beyond them, the same dead darkness as the sky.

'What are those?'

'That is the edge, the wall of the prison.'

The laughter of a group of boys echoes amongst the ruin. 
'Come,' Bassam whispers, 'we will go back.'

He leads me carefully down the rubble slope to the tunnel entrance, squats, shuffles backwards over the edge and is gone. I feel very, very alone. I lay down flat on the rocky ground and wriggle backwards like Bassam into the yawning black pit. He's waiting for me at the bottom, smoking a cigarette.

'Come, we will find Khaled.'

We walk a long way before turning down an adjoining tunnel cutting through the concrete on our left. This tunnel is lower; I have to hunch over as I walk. No concrete, just wooden beams, dirt walls and a ply wood ceiling. A few metres in, Bassam leans down and pulls a square piece of ply from against the dirt wall. Candlelight flickers through the gap. Roughly the size of a small bedroom, with a very low ceiling, dirt floor again, but the ceiling and walls are shored up with wood. Candlelight paints boxes, tools and rubbish. A pair of mattresses rest in the far corners separated by rows of unevenly stacked books. Khaled sits cross-legged, a dog-eared paperback in his hand, smiling shyly. Bassam falls onto the mattress beside him.

'Come, sit.'

I shuffle over in a low crouch and sit on the mattress facing them. 'What is this, do you live here?'

'Not me, I live with my grandmother. Khaled lives here though, he doesn't like it above ground'

I know what he means.

'You live outside? In that?

Bassam chuckles. 'It is not all like that, that is the worst of it. My grandmother's apartment is quite nice, we have power and water, sometimes, and my grandmother is a great cook.'

He says a few words to Khalid in Arabic and shifts to the edge of the mattress.

'It's late and my grandmother will be worried, I cannot stay. There is very little food and water. You will have to be careful with what you have until I can come back.'

Panic squeezes my chest. 'Please, before you go, just tell me, tell me what is going on.'

He sighs, sits back down on the mattress. 'I have told you, we found you down there, that is all. I do not know more.'

I shift my attention to Khaled and plead, 'Please,' but he doesn't reply.

'He has not said a word since his family were killed. Like I said, we do not know where you came from. We are no longer surprised when things do not make sense.'

'That tunnel, that you've dug, it is a way out? A way out of here?'

Khaled's smile widens. 'That is the plan, my friend.'

Their grinning faces don't calm me. 'But that tunnel goes down, you are digging down, why?'

Bassam sighs. 'We are digging to another world.' 


\section{'I don't understand.'}

Bassam points to the ceiling. 'Up there, you have seen it, what it is like. It is not all bad, but it is not good, and it keeps getting worse.' He sits quiet for moment. 'These tunnels once led to the outside world, they made our lives easier, but not anymore. Some parts have been flooded, in others the prison walls extend deep underground. There's no way out. We've been left here to die.'

He hesitates, but Khaled gives him a small, encouraging nod. Bassam sighs and goes on. 'Khaled and I, we do not believe it, that this is all there is, that things cannot be better. We do not believe that the world could be so cruel.' He pauses, kicking his feet across the rug. 'Reality has failed us. The world has failed us. So we have given up on both. If there is not a better life for us here, then we will dig until we find another.' He takes the paperback from Khaled and passes it to me, looking embarrassed. 'Have you read Jules Verne?' he asks very quietly.

I turn the book over in my hands; A Journey to the Centre of the Earth. 'I think I saw the movie.'

'So, you know the story?'

'Yes, I know the story, but you know it's not real, right? That it's just made up?'

Bassam laughs. 'Yes my friend, we know, but look around, does any of this seem real? Like I said, we've given up on this reality, we dig for another.' Bassam crushes out his cigarette and shuffles forward onto the edge of the mattress.

'It is time for me to go, I will come back tomorrow with food and water. You can help us dig.' not safe.'

He points towards the entrance. 'Do not go out there until I come back, it is

He mumbles something quietly to Khaled, shuffles to the entrance, and is gone. Khaled lays back on the mattress and closes his eyes. The room is utterly silent, the air still. Candlelight flickers over the low ceiling. I don't realise I'm breathing in short, ragged gasps until Khaled shakes me by the shoulder. Behind him in the shadows, the wall starts to move, creeping closer, pressing in. My breath flutters faster and shallower until the room spins and everything slides. I crash forward onto the rug, suffocating, clawing at my throat, I am being crushed. I'm only vaguely aware of Khaled hovering above me, slapping the inside of my arm. I don't feel the prick of the needle. When the void opens and offers, I slip, gratefully.

'Wake up, lad.'

A hand slaps my face and someone shakes me hard.

'Lad, wake up.'

The next slap snaps my head sideways. I open my eyes into glaring light and I blink as my vision adjusts. Peter is standing over me, impatient, frustrated.

'Get it together will you.' 
The room spins and my head pounds in slow, even throbs. I try to speak but my mouth is filled with cotton, the best I can manage is a grunt before I fold over in my chair and dry heave.

'Oh for God's sake, here.'

A bottle of water drops in my lap. I drink in deep gulps. Peter turns and walks into the storeroom.

'Come on, let's go. I have better places to be.'

I slide off the chair and teeter unsteadily through the door after him.

The storeroom is mostly empty, a handful of boxes scattered along metal shelves, a small desk and chair. My focus keeps shifting, the room dimming and brightening around me. I have to cling onto the shelving to keep myself upright as I wobble across the room. Peter looks up from a clipboard and motions me to sit in the chair.

'Alright son, you ever owned a fish tank?'

Everything is blurry, I can't remember if I've owned a fish tank but this place is large, light and comfortable so I nod.

'Similar thing here. Once a day you drop in the pellets. Rest of the time you just sit and watch. Give each box a feel every hour or so, make sure none are shaking. Vibrating's okay, we expect them to vibrate, but if they start to shake it means we've got dramas.'

He slaps the clipboard down, a list of unfamiliar names.

'That's yours. Just start at the top and work your way down. Each box gets one supply parcel per day, unless they start shaking, in which case you call me. Supply parcels are in the desk drawer. The other intern already fed them this morning, so just keep an eye on them and get used to the place.'

I stare at him blankly, my vision swimming as he straightens his suit.

'Oh, and you won't find Gaza on the shelf, they keep digging through the box walls, as you know.'

He points to a metal toolbox beside the desk.

'For the time being they're being kept in there.'

The toolbox is small but solid. luck.'

'It isn't locked. Anyway, I have to go. Someone will get you for lunch. Good

He straightens the box marked South Sudan on the shelf, and shoots me a smile on his way out. The toolbox rattles on the floor beside me. I lay my head down on the desk and close my eyes. There is so much I don't understand.

Clint Jewson studies creative writing and literature at Griffith University, Australia. His short stories have been published throughout Australia and internationally, including Talent Implied, My Favourite Apocalypse and ABC Open. 